\title{
Evaluation of the Digitalization Development level in the Latin-American Economy
}

\author{
Chavarry Galvez Diana Pamela*, and Chavarry Galvez Wilmer Paul \\ Peoples' Friendship University of Russia, Peru
}

\begin{abstract}
Latin American and the Caribbean (LAC) countries have experienced an economic slowdown in the last five years, to accelerate economic growth, LAC countries need to find new instruments to transform the economy. digitalization in all sectors of the economy gives a boost to the country's economic growth. Digital tools also promote access to better services, such as education, government management and the foreign trade sector. The article analyzes the current state of the digitalization of the economy in LAC. To determine the digitalization of the economy, only indicators found in official sources were included.
\end{abstract}

\section{Introduction}

Digital transformation has become an important global trend that creates challenges and opportunities and that, if accompanied by effective policies, can help overcome development challenges in LAC countries. While some steps have already been taken, new approaches and policies will be needed to seize the opportunities, in addition to additional investments from the public and private sectors. The 2019 Latin American Economic Outlook: Development in Transition report identifies four main development problems: low productivity, social vulnerability, institutional weakness, and environmental sustainability [1]. LAC governments cannot find a way out of the crisis that has been occurring in recent years, the LAC region has a history of facing developmental challenges: due to digital inequality, environmental degradation, the erosion of democracy, and financial debt, which have caused deep discontent among the people of the region, and this dissatisfaction has been intensified by the crises derived from the COVID-19 Pandemic [2]. Also, the sharp decline in global demand for commodities, the significant decline in commodity prices, financial instability, and other effects related to declining investment, reduced tourism, and possible reduced remittances pose a complex scenario. Overall, the region's economic growth will decline by more than $7.7 \%$ by 2021 [3]. The Internet penetration rate in the LAC countries is $69.5 \%, 10 \%$ higher than the world rate at $59.5 \%$. The great challenge and challenge of the LAC countries, in the context of falling prices of raw materials, minerals, one of the most important levers to stimulate economic growth is productivity growth, for this to increase, the digital ecosystem must grow. An idea of the scale of the challenge is given by the contribution of the knowledge economy to the growth of labor productivity: in an advanced digitalization country like South Korea, it reached 3.1 between 1995 and 2012; the average

*Corresponding author: diana_p48@hotmail.com 
of the five largest countries in LAC is 0.3 [4]. The political and economic situation is held back by inequality in access to political goods and also economic goods. In total, $68 \%$ of the region is located in the lower class, $30 \%$ in the growing middle class, and $2 \%$ in the upper class. That $68 \%$ of the lower class have half of their members in a precarious situation, some are not enough to buy food. With this, we have two groups in LAC, the one that enjoys the benefits of growth and the one that observes this growth but is not benefited [5]. The digital economy could allow governments to advance rapidly through programs that drive digitalization, innovation, and the application of these resources to the well-being of their populations. The virtual world has grown at a very high rate in the last decade, but Latin American countries for the adoption of digital products are still underdeveloped. With each passing day, more digital companies are trying to break into this digital world, as the pandemic works as a catalyst for this digital transformation. The starting point in this transformation is the development of infrastructures, such as Internet access and broadband for the public, followed by the introduction of online government services that simplify paperwork procedures for the public and foreign trade in particular. On the other hand, the digital divide between companies and the government can create serious problems for the future development of this area.

The objective of the article is to evaluate the level of development of the digital economy in Latin American countries, identifying the leading and lagging countries.

\section{Material and methods}

Methods of comparative, statistical, and logical analysis were used. For comparative analysis, socio-economic indicators were used from the databases of the World Bank; Inter-American Development Bank; the Statista internet portal; Global Innovation Index; and other open sources. A generalization method was used to formulate the conclusions. To analyze the current situation of the formation of the digital economy in Latin America and the Caribbean, the main economic sectors of each country were analyzed.

\section{Results and Discussion}

The digital economy is the economic activity that results from billions of online connections between people, businesses, institutions, and devices [6]. In today's world, technology plays a crucial role in transforming societies and economies by improving efficiency, connectivity, and access to resources and services [7]. In addition, there are several factors that influence the development of the use of digital technologies. These include: government regulation, human capital, IT research and development, innovation, business environment, information security, digital sector and digital infrastructure [8]. There are three main groups of prerequisites for the formation of the digital economy:

1. Infrastructure (computers, Internet, etc.);

2. Technologies (artificial intelligence, software);

3. Human capital (human resources, programmers, education);

4. Introduction of modern information technologies to expand foreign trade opportunities;

Each of the prerequisite groups above is related to each other, as each group is a component of the other. Today, digital technology creates another reality for governments, individuals, companies, organizations, global markets and provides a promising new growth path for any country [9]. Currently, LAC is going through a transition period towards a complete transition of the "information society". As in any transit, and the transition to digitalization, there are contradictions. On the one hand, the virtual space develops dynamically, the number of users is constantly growing and, on the other hand, the 
infrastructure remains undeveloped. At present, LAC countries are far from leading countries. To date, practically all LAC countries have adopted plans for the transition to the digital economy and have included measures such as:

I. Improvement of communication between universities and labor groups;

II. Improve the quality and use of data;

III. Increased Internet access and use of technology

IV Using Internet technologies to expand foreign trade opportunities on B2B and B2C platforms, etc.

One of the main factors that allow the development of the digital economy is the population's access to the Internet, then it must be the high speed of the Internet, that is, the development of the ICT infrastructure. If the LAC countries do not implement digitalization plans, they will be left out of the benefits of digitalization and technology, which will lead to a loss of competitiveness on the world stage and thus lag behind the developed countries and the difference gap will increase even more [10].

Table 1 analyzes the current situation of the formation of the digital economy in such sectors as public administration and education. For the analysis in the public administration sector, the following indicators were considered: Infrastructure for Innovation 2020; the ICT Development Indicators Index (maximum1.0); and the E-Government Development Index, 2018. For the analysis in the Education sector, the following indicators were considered: Human capital and research, place in the world 2020; Institutions and/or organizations, innovation creation 2020; and Public spending on education (\% of GDP-2019).

Table 1. Analysis of the current situation of the formation of the digital economy in the sectors of public administration and education in Latin America*.

\begin{tabular}{|c|c|c|c|c|c|c|}
\hline \multirow[t]{2}{*}{ Country } & \multicolumn{3}{|c|}{ PUBLIC ADMINISTRATION } & \multicolumn{3}{|c|}{ EDUCATION } \\
\hline & $\begin{array}{c}\text { Infrastru } \\
\text { cture for } \\
\text { Innovati } \\
\text { on } 2020\end{array}$ & $\begin{array}{c}\text { Index } \\
\text { develo } \\
\text { pment } \\
\text { ICT } \\
(\text { maxi } \\
\text { mum1 } \\
.0)\end{array}$ & $\begin{array}{c}\text { E- } \\
\text { Govern } \\
\text { ment } \\
\text { Develop } \\
\text { ment } \\
\text { Index, } \\
2018\end{array}$ & $\begin{array}{c}\text { Huma } \\
\mathbf{n} \\
\text { capital } \\
\text { and } \\
\text { resear } \\
\text { ch, a } \\
\text { place } \\
\text { in the } \\
\text { world } \\
2020 \\
\end{array}$ & $\begin{array}{c}\text { Institution } \\
\text { s and / or } \\
\text { organizati } \\
\text { ons, } \\
\text { creating } \\
\text { innovatio } \\
\text { n 2020 }\end{array}$ & $\begin{array}{c}\text { Govern } \\
\text { ment } \\
\text { spendin } \\
\text { g on } \\
\text { educati } \\
\text { on }(\% \text { of } \\
\text { GDP) - } \\
2019\end{array}$ \\
\hline Panama & 47 & 0,454 & 85 & 101 & 67 & $\mathrm{H} /$ Д \\
\hline Colombia & 50 & 0,441 & 61 & 82 & 57 & 4.5 \\
\hline Chile & 51 & 0,537 & 42 & 55 & 38 & 4.9 \\
\hline Uruguay & 52 & 0,696 & 34 & 71 & 46 & H/д \\
\hline Mexico & 59 & 0,441 & 64 & 58 & 74 & 5.3 \\
\hline Brazil & 61 & 0,522 & 44 & 49 & 82 & 5.9 \\
\hline Costa Rica & 62 & 0,634 & 56 & 66 & 66 & 7.1 \\
\hline Peru & 68 & 0,391 & 77 & 57 & 72 & 3.8 \\
\hline Argentina & 70 & 0,592 & 43 & 48 & 97 & 5.9 \\
\hline $\begin{array}{l}\text { Dominican } \\
\text { Republic }\end{array}$ & 77 & 0,365 & 95 & 100 & 98 & н/д \\
\hline Ecuador & 82 & 0.369 & 84 & 91 & 126 & 5 \\
\hline Paraguay & 89 & 0.35 & 108 & 98 & 109 & 5 \\
\hline El Salvador & 101 & 0.381 & 100 & 105 & 100 & 3.5 \\
\hline Bolivia & 104 & 0,314 & 103 & 56 & 129 & 7.3 \\
\hline Honduras & 109 & 0,226 & 123 & 99 & 125 & 5.9 \\
\hline Guatemala & 113 & 0,294 & 113 & 123 & 117 & 2.8 \\
\hline
\end{tabular}


The analysis revealed (tab.1) that LAC countries are divided into 3 groups into developed, medium, and underdeveloped. The developed countries of the LAC region in public administration with intervention and use of digital transformation are Chile, Uruguay, Brazil, Colombia, and Argentina. The medium-developed countries in public administration are Panama, Mexico, Peru, the Dominican Republic, and Ecuador. With much difference and much less development, occupying the last places in the region and the world, countries such as Honduras, Guatemala, Bolivia, Paraguay, and El Salvador, have little development of infrastructure for innovation and the development of ICT is very low. The role of government management is vital for the success of digital development, but it must fulfill 5 synergistic steps to achieve this successful transformation which is: leadership, action plan, resources, legislative framework, digital architecture [11]. Data from LAC show that a higher rate of development of electronic government and public bodies directly affects organizations and institutions that in turn directly affect the formation of the population, that is, human capital. On the other hand, it is directly related to institutions and organizations dedicated to training, learning, and innovation. The electronic government uses the ICT infrastructure, and especially the Internet, as a tool to improve public administration. The countries with the highest development of infrastructure for innovation and the ICT development index are leaders in the development of public administration, so it should be emphasized that investment in ICT infrastructure is the starting point for the development of the digital economy and also public administration and the need to think about how digitalization will be used, so the government must create programs that are attractive to the population and increase trust in public administration. In this way, it is possible to reduce costs and streamline in time and efficiency the procedures of the population that make them more reliable, efficient, inclusive, and innovative. On the other hand, the creation of central citizen service agencies with online procurement procedures such as specialized procurement and contracting centers, and the development of electronic procurement and contracting solutions (for example, "Chilecompra" and "Colombiacompraefectivo») transform traditional practices. Managing digital transformation is a fundamental issue of public policy. Changes in institutions, regulations, and markets are necessary to ensure that the digital transformation proceeds fairly and equitably. Governments face new regulatory challenges not only in managing the resulting aspects of digital transformation but also in ensuring that its benefits reach the entire population [12].

Developed countries have invested in human talent in less common fields, such as systems engineering, data science, or artificial intelligence. The countries with the highest investments in their GDP are at the forefront in indicators such as human capital and the desire for innovation. The accumulated human capital realized through labor potential becomes in turn a key factor in the economic development [13]. The developed countries of LAC in education with intervention and use of digital transformation are Brazil, Costa Rica, Chile, Uruguay, and Argentina. These countries have higher spending on education, compared to their share of GDP, and they also have the highest human capital and research level in the Latin American region.

The countries of medium development in the education sector are Panama, Colombia, Peru, Mexico, the Dominican Republic, and Bolivia, although the latter lacks the creation of innovative institutions and organizations, it is noteworthy that it invests the highest percentage of GDP in education in the LAC region 7.3\%.

The underdeveloped countries in education are Guatemala, El Salvador, Honduras, Paraguay, Ecuador. These countries lack innovative institutions and organizations and have a low economic investment in education, for example, Guatemala uses only $2.8 \%$ of its GDP. Increasing the human capital of countries allows them to be at the forefront and to be competitive in the globalization process. LAC needs new strategies, new leaders, new markets to improve its economy, and it urgently needs innovative ideas that create an 
environment conductive to economic growth in the region. One of the uses of digitalization is to be able to educate the population, investment in education has a direct return on human capital, which allows socio-economic progress. One of the alternatives is through online schools, it will allow educating the population and will be a great step to begin to eradicate the deficit in the education of the LAC population, more than $5 \%$ of the students had access to the Internet and other digital technologies exclusively through your educational institution. Therefore, it is also necessary to expand the Internet connection in educational institutions. For example, around $95 \%$ of computers in OECD educational institutions had an Internet connection, compared to $74 \%$ in LAC [14]. In general, the region's economy is not technological and has low labor productivity. Therefore, the innovation is weak and the results are very low. Regional leaders in innovation 2020 include Chile, Panama, and Colombia. The middle group of countries includes Uruguay, Mexico, Brazil, and Costa Rica. The lagging countries are Bolivia, Honduras, and Guatemala.

Table 2 analyzes the current situation of the formation of the digital economy the LA countries were analyzed in the following sectors: business sector, population and households. For the analysis in the business sector, the following indicators were considered: e-commerce turnover (millions of dollars in 2020); and Business Development in 2020. For the analysis in the population and household sector, the following indicators were considered: Technology development and the knowledge economy 2020; Creative activity results -2020 ; Human component capital 2018; and Internet penetration rate in \%.

Table 2. Analysis of the current situation of the formation of the digital economy in the business, population and household sectors in Latin America*.

\begin{tabular}{|c|c|c|c|c|c|c|}
\hline \multirow[t]{3}{*}{ Country } & \multicolumn{2}{|c|}{ BUSINESS SECTOR } & \multicolumn{4}{|c|}{ POPULATION AND HOUSEHOLDS } \\
\hline & \multirow{2}{*}{$\begin{array}{c}\text { E-commerce } \\
\text { turnover, } \\
\text { millions of } \\
\text { dollars, 2020 }\end{array}$} & \multirow[t]{2}{*}{$\begin{array}{c}\text { Business } \\
\text { Development } \\
2020\end{array}$} & \multicolumn{2}{|c|}{$\begin{array}{l}\text { Results obtained from } \\
\text { the implementation of } \\
\text { innovations-2020 }\end{array}$} & \multirow{2}{*}{$\begin{array}{c}\text { Human } \\
\text { Compone } \\
\text { nt } \\
\text { Capital- } \\
2018\end{array}$} & \multirow{2}{*}{$\begin{array}{c}\text { The level } \\
\text { of } \\
\text { Internet } \\
\text { penetrati } \\
\text { on, in \% }\end{array}$} \\
\hline & & & $\begin{array}{l}\text { Developme } \\
\text { nt of } \\
\text { technologies } \\
\text { and the } \\
\text { knowledge } \\
\text { economy- } \\
2020\end{array}$ & $\begin{array}{c}\text { Results } \\
\text { of } \\
\text { creative } \\
\text { activity } \\
-2020\end{array}$ & & \\
\hline Chile & 5269 & 49 & 64 & 61 & 0.8339 & 92.4 \\
\hline Mexico & 18764 & 59 & 55 & 54 & 0.7044 & 69.5 \\
\hline Costa Rica & 1083 & 48 & 53 & 53 & 0.7933 & 72.1 \\
\hline Brazil & 21173 & 35 & 56 & 77 & 0.7525 & 70.1 \\
\hline Colombia & 5386 & 52 & 72 & 80 & 0.7382 & 70.6 \\
\hline Uruguay & 529 & 85 & 63 & 62 & 0.7719 & 88.1 \\
\hline Panama & 457 & 123 & 91 & 55 & 0.7137 & 67.2 \\
\hline Peru & 2943 & 43 & 112 & 87 & 0.7276 & 66.8 \\
\hline Argentina & 5526 & 61 & 75 & 71 & 0.8579 & 92 \\
\hline $\begin{array}{l}\text { Dominican } \\
\text { Republic } \\
\end{array}$ & 950 & 83 & 99 & 82 & 0.6927 & 75.8 \\
\hline El Salvador & 379 & 76 & 110 & 74 & 0.6348 & 58.6 \\
\hline Paraguay & 387 & 84 & 115 & 78 & 0.6701 & 88.5 \\
\hline Ecuador & 904 & 97 & 105 & 92 & 0.7395 & 76.4 \\
\hline Honduras & 117 & 74 & 97 & 104 & 0.6015 & 41.7 \\
\hline Bolivia & 279 & 90 & 114 & 109 & 0.7148 & 75.5 \\
\hline Guatemala & 330 & 82 & 116 & 81 & 0.5524 & 44.2 \\
\hline
\end{tabular}

*Source: $\quad$ https://www.globalinnovationindex.org/;

https://internetworldstats.com/. https://publicadministration.un.org/; http://hdr.undp.org/ and InterAmerican Development bank.

In the analysis in Table 2, the developed countries in the LAC region in the business sector with intervention and use of digital transformation are Brazil, Costa Rica, Chile, 
Colombia, and Mexico. These countries have the highest volume of electronic commerce, and this is the engine of business development; But these countries have achieved quite high e-commerce growth rates, but even so, the gap and lag with world leaders is significant. The countries with medium development in the business sector are Uruguay, Ecuador, Peru, Argentina, the Dominican Republic, and El Salvador. The underdeveloped countries in the business sector are Panama, Guatemala, Bolivia, Honduras, and Paraguay.

In the business sector in many countries of the world, the penetration of digital technologies into the lives of the population began with the emergence and spread of electronic commerce, electronic commerce is becoming the core of the digital economy. In LAC countries, the only Internet company is "Mercado Libre". With digital platforms, ecommerce can expand markets and achieve improved efficiency. Firms have been developing innovative marketing methods to learn about consumer preferences. One of the requirements to increase the use of electronic commerce is the transport infrastructure and logistics that should promote competitiveness and electronic commerce. On the other hand, the diffusion and impact of digital technologies on productivity and entrepreneurship in LAC are not automatic but depend on necessary elements such as adequate access and diffusion of digital technologies, business dynamics, participation of small and medium-sized enterprises in digital transformation, and sufficient competition in the digital economy.

The developed countries of LAC in the population and household sector with the intervention and use of digital transformation are Chile, Costa Rica, Brazil, Argentina and Mexico, although the latter country has a low percentage of Internet penetration. These countries are leaders due to their development in innovation; human capital and a large percentage of its population have access to the Internet. The medium-developed countries in the Latin American region in terms of population and households are Colombia, Uruguay, Panama, Peru, the Dominican Republic and Paraguay. The underdeveloped countries are El Salvador, Ecuador, Honduras, Bolivia and Guatemala. These countries have a very low Internet penetration rate of less than $50 \%$ in the case of Guatemala and Honduras. Besides not developing and promoting innovations; they occupy the last places in the region and the world; they have a large deficit in their human capital indicators.

According to comparative analysis in different sectors of public administration, the education, business sector, and population, and households for this digital transition vary greatly between countries in the Latin American region. After analyzing the current situation of the formation of the digital economy, the countries of Latin America were grouped into the most developed, medium-developed, and underdeveloped.

- The developed countries are Chile, Mexico, Argentina, Brazil, and Uruguay.

- Middle-developed countries are Costa Rica, Colombia, Peru, Panama, and the Dominican Republic.

- Underdeveloped countries are Ecuador, Paraguay, El Salvador, Bolivia, Honduras, and Guatemala.

\section{Conclusions}

The data shows that the first group of the developed LAC countries, in the population sector also have a high level of development with the use of digital instruments in the sectors of public administration, education, business sector, and have implemented digital plans in their governments, have all the requirements to achieve greater socioeconomic development and be globally competitive. In many indicators and indices, these countries occupy the Top 50 in the world. In other words, they are in the first third of all the countries in the world. The governments of these countries are adopting public policies to guarantee a rapid response and effectively articulate the digital transformation process as a key factor in social security. 
The difference between developed and middle-developed countries in the LAC region in some indicators is quite large. This second group of countries are competing for development and have a quality ICT infrastructure and also the number of their population with Internet access is greater than the LAC average. But this group has a deficit in search and innovation and a lack of e-commerce development that could be a catalyst for the development of the digital economy. To prevent existing inequalities in the region from deepening, and technology benefits everyone equally, countries must increase access to these technologies and ensure that the necessary skills reach educational institutions, students, households, and workers.

The third group of underdeveloped countries in LAC does not have a qualitative development of ICT, the percentage of the population that has access to the Internet is lower than the average for the LAC region. On the other hand, its human capital and its educational system have a shortage of research and innovation. These countries must carry out reforms and changes in their main sectors, otherwise, they will continue to lag behind global competitiveness and, in the future, they will not be able to take advantage of all the opportunities that digital transformation will allow them. The digital transformation affects the quality of life of households, employment, and education. New technologies offer ample opportunities to access better public services, improve education, as well as to better integrate sectors with fewer economic resources in public policies. In the near future, workers who do not have access to new technologies or the necessary skills will be vulnerable to economic losses, they will not be able to take advantage of all the benefits of digitalization such as working remotely, selling products online, and access to platforms educational.

\section{References}

1. OECD, et al., Latin American Economic Outlook 2019: Development in Transition (2019)

2. M. A. Gonzalez-Perez, M. Mohieldin, G. T. M. Hult, J. Velez-Ocampo, Management Research (2021)

3. CEPAL, Enfrentar los efectos cada vez mayores del COVID-19 para una reactivación con igualdad: nuevas proyecciones (2020)

4. R. Katz and F. Callorda, Telecommunications Policy, 42 (2018)

5. L.V. D'yakova, World Economy and International Relations, 64 (2020)

6. Technology and Innovation - A Catalyst for Development (2017)

7. Innovation and Technology for Sustainable Development (2017)

8. National program «Digital economy of the Russian Federation», State Corporation ROSATOM (2018)

9. A. Khalimon, M. N. Guseva, I. Z. Kogotkova, I. S. Brikoshina, The European Proceedings of Social \& Behavioural Sciences EpSBS, 57 (2018)

10. S. Yu. Revinova, D. Chavarri, Proceedings of the 2nd International Scientific and Practical Conf. "Modern Management Trends and the Digital Economy: from Regional Development to Global Economic Growth" (2020)

11. M. Acosta, A. Y. Velastegui, Perez, 3C COMPANY, 7 (2018)

12. OECD, Profiling the digital transformation in Latin America: Higher productivity for a better life (2019)

13. O. G. Ogiy, V.I. Kuzin, A.G. Harin, IOP Conf. Series: Earth and Environmental Science, 689 (2020)

14. Latin American Economic Outlook, Digital transformation for better reconstruction (2020)

15. Oleg N. Zhilkin, Wilmer Paul Chavarry Galvez Analysis of current trends in assessing the country's potential in international trade (on example of Peru) (2020) 